\title{
Успадковані спогади: Ольга Гоффманн vel Ткачук повертає пам'ять про батька
}

„Я є Ольга Гоффманн vel Ткачук” - з великою гордістю і доньчиною любов’ю заявляла про свою кровну й духовну спорідненість єдина дитина Василя Ткачука ${ }^{1}$ — „забутого імені” української літератури.

Ольга Гоффманн не знала і не пам'ятала батька. Народилася 1938 року. Василь Ткачук покинув сім'ю у 1940-му році, коли дочці не виповнилося їще двох років. Помер письменник, імовірно, 1944 року, далеко від України, у Східній Прусії, але на той час його дочка вже щонайменше чотири роки виховувалась без батька.

Чому ж тоді усе своє свідоме життя Ольга Гоффманн шукала батька у спогадах матері й бабусі, чому на схилі віку пізнала його творчість, читаючи батькові книжки, що їх отримала від Романа Ризюка - багатолітнього директора Народного Музею історії села Іллінці, врешті, перевидаючи його „малу прозу” однією книгою (Сині чічки, 2013), чому ії глибоким праг-

1 Про життєвий та творчий шляхи Василя Ткачука (1916-1944) - українського новеліста 30-х років XX ст. дивись детальніше, між іншим, у статтях: A. Horniatko-Szumiłowicz, „, Skromne obrazki wiejskie” Wasyla Tkaczuka (szkic do portretu pisarza zapomnianego), „Studia et Documenta Slavica" 2017, № 1, c. 9-21; A. Horniatko-Szumiłowicz, Майстерність змалювання жіночих постатей в новелістииі Василя Ткачука, [в:] Kobieta w zwierciadle języka i kultury, ред. A. Archangielska, M. Hordy, Szczecin 2017, c. 481-499; А. Горнятко-Шумилович, Буря Василя Ткачука (Про забуту новелу „, Загубленого таланту”), „Studia Ukrainica Posnaniensia” 6, 2018, c. 197-205; А. Горнятко-Шумилович, Символ чічки в новелістищі Василя Ткачука, „Studia Ukrainica Posnaniensia” 7, 2019, с. 165-173; A. Horniatko-Szumiłowicz, Василь Ткачук. Між традииією і новаторством. Нарис проблематики, [в:] Tożsamość ukraińska wobec przemian XVII-XXI w., ред. K. Jakubowska-Krawczyk, A. Nowacki, Lublin 2017, c. 141-157; A. HorniatkoSzumiłowicz, На терезах долі (Мотиви й образи смерті у новелістиці Василя Ткачука), „Slavica Wratislaviensia" 168, 2019, c. 123-135. 
ненням було і є відновити пам'ять про Василя Ткачука ${ }^{2}$, що захована в його маловідомих широкому загалу чотирьох збірках новел, в ентузіастичних оцінках забутих сьогодні критиків 30 -х років, в українських архівах, урешті, в нечисленних спогадах друзів і родичів?

Перш ніж відповісти на поставлене вище питання, слід зазначити, що окрім літературно-критичної спадщини $30-$ х років ${ }^{3}$, в якій обговорювались актуальні питання творчості „Гуцулика”", залишилося небагато безпосередніх спогадів про письменника, зафіксованих у писемній формі, як, наприклад, спомини товариша Ткачука 3 „Дванадцятки” - Остапа Тарнавського, поміщені в його книжці Літературний Львів. 1939-1944 $(1995,2013)$. У львівських архівах та музеях збереглися метричні книги із свідоцтвом про вінчання Василя Ткачука і Марії Януш, свідоцтвом про народження Ольги Гоффманн, лист Василя Ткачука до приятеля із „Дванадцятки” Івана Керницького, унікальний лист Марії Януш — дружини письменника з проханням допомогти з'ясувати місце перебування Ткачука до того ж Івана Керницького. Копії указаних документів стали власністю Ольги Гоффманн за посередництвом Романа Ризюка, якого вона мала змогу пізнати за сприянням пароха парафії Покрови Пресвятої Богородиці УГКЦ у Щецині - отця Роберта Роси. А отже, спогади Ольги Гоффманн - успадковані, оскільки з одного боку, дійшли до неї у формі згаданих вище писемних спогадів і документів, $з$ другого, передані їй усним шляхом членами сім'ї, зокрема її бабусею Мартою - тещою Василя Ткачука,

2 У 2013 році дочка письменника видала книжку Сині чічки (див. В. Ткачук, Сині чічки. Новели, передм. Х. Синітович, Івано-Франківськ 2013), в якій поміщені новели із чотирьох прижиттєвих збірок Ткачука (Сині чічки, 1935; Золоті дзвінки, 1936; Зимова мельодія, 1938; Весна, 1940). Примірники книжки розіслані нею зокрема до великих університетьских бібліотек України і Польщі, україністичних центрів в Мюнхені і Торонто. У 2016 році - в соту річницю від дня народження письменника Ольга Гоффманн опублікувла дві статті про батька — в „Українському альманаху” (див. О. Гоффманн, До сторіччя з дня народження Василя Ткачука - спогади дочки письменника, „Український альманах” 2016, с. 260-270) і „Нашому Слові” (див. О. Гоффманн, Хто такий Василь Ткачук. До сторіччя з дні народження, „Наше Слово", 17.01.2016, с. 10). Наміром спадкоємиці творчості галицького новеліста є також видати кільканадцять ніколи непублікованих у книжковій формі Ткачукових новел, що друкувались поодинці на сторінках львівських журналів 30-х років.

Окрім того на Щецинському цвинтарі Ольга Гоффманн облаштувала батьку символічну могилу. Там теж вмурувала кілька камінців, привезених на її прохання Іваном Сирником (головою Щецинського відділу Об’єднання українців у Польщі (ОУП) з рідних Іллінців.

3 Див. детальніше на цю тему: А. Horniatko-Szumiłowicz, „Skromne obrazki wiejskie” Wasyla Tkaczuka (szkic do portretu pisarza zapomnianego)...

4 „Гуцуликом” називали Василя Ткачука, який походив із села Іллінці Снятинського повіту на Станіславщині, члени львівського угрупування „Дванадцятка”, до якого належав і він сам. Анатоль Курдидик називав так свого товариша по перу і в газетних публікаціях, зокрема в рецензії на першу книжку новеліста — Сині чічки, 1935 („Неділя” 1936, ч. 21) та в огляді - серед претендентів на літературну нагороду Товариства українських письменників і журналістів ім. І. Франка за 1935 рік. Див. Дванадиятка. Наймолодма львівська літературна богема 30-х років XX століття: Антологія урбаністичної прози, за ред. В. Габора, Львів 2006, c. 295.

Slavica Wratislaviensia 173, 2020

(C) for this edition by CNS 
Марією Януш (Марією Павловською по другому чоловіку) — його дружиною і матір'ю Ольги Гоффманн, Анною Федорійчук — племінницею письменника і троюрідною сестрою дочки письменника. Спогади вказаних вище жінок стали безцінним джерелом для пізнання Ольгою Гоффманн життя, обставин смерті і певних аспектів творчості ііі батька — „загубленого таланту”5.

Повертаючись до поставленого скоріше питання про потребу і сенс пошуків Ольгою Гоффманн батька у спогадах інших, слід зазначити, що відповідь на нього найімовірніше закладена у феномені постпам'яті і психологічних механізмах, що спрацювують у свідомості людини, яка успадковує спогади.

Теорія постпам'яті або успадкованої пам'яті про події з минулого, конкретну людину чи групу людей пов'язана з постаттю Маріанни Гірш, яка вперше застосувала категорію постпам'яті в 1992 році в інтерпретації графічного роману Маус. Розповідь того, хто вижив (англ. Maus. A Survivor's Tale) автора коміксів Арта Спігельмана ${ }^{6} .3$ того часу американська дослідниця присвячувала свої праці питанню постпам'яті і зокрема творчості другого покоління євреїв, які іммігрували в США, але зберегли свою ідентичність через успадковану пам'ять про колективну травму своїх предків.

Відтак, постпам'ять зумовлює потребу у відновленні, збереженні, урешті плеканні переказаних, почутих, але особисто не прожитих історій, що вибудовують систему спогадів. Ярослав Поліщук ${ }^{7}$ констатує, за американською дослідницею, що сила впливу вторинної (успадкованої) пам'яті настільки вагома, що їі можна порівняти із власне пам'яттю, незважаючи на значну часову відстань між другим і першим (травмованим) поколіннями. Звідти, як справедливо зауважує український дослідник, „постає феномен, коли постпам’ять

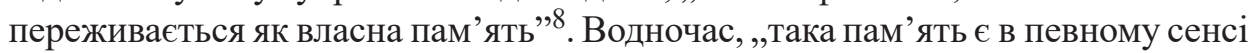
фальшивою, адже формується на підставі не власного досвіду пережитого, а непрямих свідчень, властиво спогадів старших (усних чи записаних), зацілілих речей, зокрема документальних фотографій"я.

Ідею постпам'яті можна застосувати і до українських суспільно-культурних реалій, як це, наприклад, зробив згаданий Поліщук, який проналізував роман Ліни Костенко Записки украйнського самошедшого (2010) крізь призму вказаної вище теорії ${ }^{10}$. Можна і запропоновану Маріанною Гірш теорію накласти і на ситуацію Ольги Гоффманн. Бо ж, чи подібні механіз-

5 Див. Р. Горак, Загублений талант Василя Ткачука, [в:] В. Ткачук, Золоті дзвінки, підготовка текстів, упоряд. та післяслово Романа Горака, Львів 2014, с. 238-303.

6 Див. M. Hirsch, Family Pictures: Maus, Mourning and Post-Memory, „Discourse: Journal for Theoretical Studies in Media and Culture” 1992-1993, т. 15, № 2 , c. 3-29.

7 Див. Я. Поліщук, Пам'ять і постпам'ять (на матеріалі роману Ліни Костенко „, Записки украйнського самашедшого”), [в:] Постколоніалізм. Генерачії. Культура, за ред. Т. Гундорової, А. Матусяк, Київ 2014, с. 163.
8 Ibidem.
9 Ibidem.
${ }^{10}$ Ibidem.

Slavica Wratislaviensia 173, 2020

(C) for this edition by CNS 
ми спрацювали в неї? Безперечно, принаймні частинно так. А отже метою статті $€$ проаналізувати спогади, рефлексії й думки дочки письменника про батька, обставини його смерті та творчість, у першу чергу зафіксовані нами під час інтерв'ю $з$ донькою письменника від 4 серпня 2018 року і короткій розмові від 1 квітня 2019 року.

На поставлене нами Ользі Гоффманн питання, коли вирішила для себе, що важливим в іiї житті буде відновити пам'ять про батька, дочка письменника вказала на пору безпосередньо після смерті їі матері і жінки Василя Ткачука - Марії Януш, яка „плачучи, журилася, що постать творця і її коханого чоловіка відійде в забуття” ${ }^{11}$. „Коли прийшов момент відходу з життя і час порожнечі, - зізнавалась далі Ольга Гоффманн, - я зрозуміла, що моєю метою стало виконання волі Моєї Матері”"12.

Повертаючи пам'ять про Василя Ткачука, Ольга Гоффманн повертає собі й українській культурі трьохіпостасний його образ: людини і батька жертви нової радянської влади — творця.

\section{Образ людини і батька}

У трьохіпостасному портреті Василя Ткачука, що визрів в уяві дочки письменника, чи не найціліснішим є образ людини i, зокрема, батька. Окремі штрихи до його образу успадкувала вона з нечисленних спогадів матері і бабусі. Зокрема остання говорила небагато і „, не завжди добре”, оскільки, за словами Ольги Гоффманн, уважала, що „шлюб дочки з Ткачуком зруйнував iі життя”. Коли бабуся була чимось невдоволена, називала іiі „цілим татусем”. Ольжина мати також не була велемовною. На думку моєї співрозмовниці, мати хотіла оберегти дочку від смутку. Водночас Ткачук був найбільшою любов’ю Марії Януш і в ході прогресування старечої деменції Ольжина мати не скривала більше своєї туги, дедалі частіше прикликуючи улюбленого чоловіка: „Василю, де ти?”. Звідти конклюзія Ольги: „Думаю, що з цілого життя пам’ятала тільки Його, свою велику любов"13. Щодо своїх особистих відчуттів, дочка письменника висловила підсвідомий жаль до батька: „лише двохлітньою дитиною була покинута Ним, а мої батьки розійшлися" 14 .

Окрему роль для формування образу батька в постпам'яті Ольги Гоффманн відіграли старі фотографії, що вона підтвердила у розмові з нами: „На щастя збереглися знімки, на основі яких формувався в мене образ Батька" 15 .

11 Інтерв'ю з Ольгою Гоффманн від 4 серпня 2018 року. Приватний архів авторки статті.

12 Ibidem.

13 Ibidem.

14 Працюючи над даною статтею, ми звернулися до Ольги Гоффманн з проханням розповісти про своє ставлення до збережених в її приватному архіві фотографій. Нас цікавило, яке значення вони мають для неї, котра 3 них найбільш дорога ӥй серцю тощо. Пані Ольга Гоффманн після телефонної розмови $з$ нами, висловила свої думки на писмі. Див. Розмова з Ольгою Гоффманн від 1 квітня 2019 року. Приватний архів авторки статті.

15 Ibidem. 
Світлина, на якій маленька восьмимісячна донька позує разом 3 батьком - найближча серцю моєї співрозмовниці (,Здається мені, що була для нього важливою «людинкою». Підтверджує це його теплий погляд. Такого зберегла у своїй пам'яті"'16). Дійсно, Ткачук із батьківською ніжністю дивиться на свою „Куку” ${ }^{17}$. Це улюблена фотографія Ольги Гоффманн, яка потрапила до всіх сучасних книжкових опрацювань творчості Ткачука. Вона поміщена, між іншим, у вступі Христини Синітович, що попереджає збірне видання новел Ткачука Сині чічки (2013) ${ }^{18}$, але також у післямові Загублений талант Василя Ткачука, авторства Романа Горака, доданого до книжки Золоті дзвінки (2014) ${ }^{19}$. Фотографія батька 3 дочкою знайшлась також на сторінках біографічної статті, авторства самої Ольги Гоффманн, що поміщена в Українському альманаху з 2016 року $^{20}$.

Окрім згаданої світлини, в архіві доньки письменника збереглось ще кілька родинних фотографій, серед яких найчастіше експоновані знімки подружжя Ткачуків на тлі мальовничого пейзажу в Яремчі і перед хатою в Дорі ${ }^{21}$, які „приковують увагу” Ольги Гоффманн (пор. „Моя Мати задивлена в коханого чоловіка і Він, який висувається на перший план — елегантний, шикарний мужчина"), портретна світлина молодого письменника з матір'ю - Оленою Ткачук (пор. „Особливу увагу привертає знімок Василя з його Мамою, котру по-справжньому любив, хоча фотографія не віддзеркалює цього. Знов немовби хотів показати себе" 22 , кілька фотографій, найчастіше портретних, самого Ткачука (Ольга Гоффманн згадує про дві з них — Ткачук на лижах і в елегантному костюмі перед хатою в Дорі - „гонористий, немовби «пан із великого маєтку»"23), урешті, світлина, що зображає дорогі серцю новеліста жінки - дружину Марію, матір Олену, сестру Марійку і малолітню дочку Ольгу. Знімок зроблений на городі перед іллінецькою хатою в половині сорокових років, імовірно вже після смерті письменника. За словами Ольги Гоффманн,

16 Ibidem.

17 Так пестливо Василь Ткачук звертався до своєї маленької дочки. Ольга Гоффманн згадувала: „Моя мама і найближчна родина називали мене «Кукою» багато років”. Див. IHтерв'ю з Ольгою Гоффманн від 4 серпня 2018 року...

18 Див. Х. Синітович, Життєвий і творчий шлях Василя Ткачука, [в:] В. Ткачук, Сині чічки, Івано-Франківськ 2013, с. 5-13.

19 Див. Р. Горак, Загублений талант Василя Ткачука.., с. 291.

20 Див. О. Гоффманн, До сторіччя з дня народження Василя Ткачука - спогади дочки письменника..., с. 262.

21 Дора - колишнє давнє село, розташоване поблизу міста Яремче (сьогодні входить до його складу). За успадкованими спогадами Ольги Гоффманн, саме там молодий новеліст мав можливість присвятитися творчій праці, пор. „Моя мати згадувала про старшого за мого батька художника, який оточував його своїм меценацтвом, створюючи умови для творчої праці. Запросив молоде поружжя до своєї гірської хати в Дорі, щоб батько далеко від міської метушні міг присвяти себе творчості. На жаль, не пам'ятаю імені [художника. — А. Г.-Ш.]”. Див. Інтерв'ю з Ольгою Гоффманн від 4 серпня 2018 року...

22 Розмова з Ольгою Гоффманн від 1 квітня 2019 року...

23 Ibidem. 
фотографія закарбувалася в її пам' яті, оскільки, „будь-що-будь я вже більшенька дівчинка, пригадую двір і зокрема жолоб для напування худоби”24.

Згадані фотографії мають високу емоційну цінність для дочки письменника, яка черпає з них уривчасті інформації про життя по суті невідомого для неї батька.

Водночас, згідно з дослідниками, фотографія знищує пам'ять, перебуває до неї в опозиції, оскільки показує об'єкт у стерильній закінченості. Такі мислителі, як Зигфрід Кракауер, Вальтер Беньямін чи Ролан Барт стверджували, що фотографія руйнівна для пам'яті: саме пам'ять зберігає „істинний зміст” індивіда, „останній образ” життя (Кракауер), тоді як фотографія — „протилежність спогаду” (Барт) і втягнена в „руйнування аури” (Беньямін) ${ }^{25}$. Відтак, фотографічний „погляд” не є фіксатором реальності, якою вона є. „Об’єктивної” фотографії не існує, оскільки він від початку вибірковий чи певним чином естетизований. Подібну думку висловила Маріанна Гірш, яка, аналізуючи цикл світлин з чернівецьких вулиць $30-40$-х років, вказує на величезну розбіжність між тим, що бачимо (радісних людей, які гуляють вулицями міста) і тим, що нам відомо (ці люди є свідками й учасниками жорстокої війни) ${ }^{26} .3$ одного боку, вони, „стираючи” втрату і смерть, віддзеркалюють життя, що проходило поруч жахів війни, з другого - $є$ своєрідними „відблисками” воєнного хорору ${ }^{27}$.

У світлі сказаного, фотографії, збережені в архіві Ольги Гоффманн, показують позірно безтурботне життя Василя Ткачука до його арештування у 1940-го року і насильного призову в армію. Уважний аналіз світлин віддзеркалює прагнення Ткачука до кращого життя, його бажання стати міською людиною (елегантні Ткачук з дружиною на відпочинку в Яремчі; Ткачук-лижник тощо) при одночасному збереженні святості власного коріння (знімок Ткачука 3 матір'ю). Тільки одна портретна фотографія зроблена у 1940-му році, тобто безпосередньо перед арештом, стаючи згаданим вище своєрідним „проблиском” хорору.

\section{Образ жертви}

Безпосередньою причиною передчасної загибелі Василя Ткачука Ольга Гоффманн уважає політичну систему, в якій довелось жити і творити батькові, але і його непокірну вдачу. На їі думку, батькові прийшлось деміфологізувати радянську владу, що брутально вторгнула в життя галичан осінню 1939го року. Початкове захоплення батька феноменом радянського „визволителя” від польського ярма, Ольга Гоффманн виправдовує суцільною комунізацією

24 Ibidem.

25 Див. В. Черепанин, Проявлені фотографологіï, 2004, https://t.ua/CULTURE/proyavleni_fotografologiyi.html [доступ: 19.02.2020].

26 Див. А. Ubertowska, Praktykowanie postpamięci. Marianne Hirsch i fotograficzne widma z Czernowitz, „Teksty Drugie” 2013, № 4, c. 282.

27 Див. ibidem, с. 283. 
тогочасного українського суспільства, зокрема бідних селян. Як зазначає в інтерв'ю,

мій батько був від наймолодших літ під впливом комуністичної ідеології, вірив в ії правомірність. Важко цьому дивуватися, оскільки зростав у бідній сім’і, виховуваний матір'ю, удовою, яка заробляла на утримання двох синів, Олександра й Василька, і дочки Марійки послугами, вишиванням ${ }^{28}$.

Поступово однак молодий письменник бачить розрив між словом і ділом, „різниці між теорією і практикою” нової радянської влади і починає бунтуватись. „Відважний, привселюдно висловлює свою думку, критикує дії партійних ідеологів. [...] нависають над ним чорні хмари. Арештують непокірливого гуцула і слід за ним пропадає"29. Його норовлива вдача і юнача наївність призвели до трагедії - насильного призову в армію і скорої загибелі. Такий образ батька зарисовується в уявленні Ольги Гоффманн із зафіксованих в успадкованих від матері, бабусі, а згодом родички Анни, спогадах.

Важко дивуватися, - згадувала в розмові з нами від 1 квітня цього ж року, - це молодий хлопець 3 усебічними зацікавленнями, який добився успіху. Цінує свою вартість, свої багатогранні таланти, пише вірші, танцює в ансамблі, деякий час навіть його очолює. Усе це призводить до того, що прагне більше і більше, що з часом стає згубним ${ }^{30}$.

На їі думку, „хлопчина, перед яким розгорнулися двері у великий світ, не зміг, на жаль, витримати тягару такого успіху і раціонально розпоряджатися ним. Стає пихатим, гордовитим, неодноразово суперечливим"31.

Успадковані спогади про трагічну смерть батька (за непідтвердженими даними Василь Ткачук мав загинути розчавлений танком) посилили в дочці письменника тривале почуття невтішної втрати. Як важливий носій інформацій вона відчуває обов'язок перед нащадками зберегти пам'ять не лише про його творчість, але й про життя, утім обставини смерті. Звідти ії ідея облаштувати символічну могилу, про що розповіла в інтерв’ю:

Заради того, щоб перехожий мав змогу зупинитися і задуматись, я встановила на Центральному цвинтарі у Щецині, в оточенні могил моєї родини невеликий камінь, символічну могилу In Memoriam. Як відомо, мій батько ніде не має могили, бо ж загинув під час боїв у Східній Прусії. Можу запалити свічку і на хвильку задуматись. На моє прохання голова Іван Сирник привіз крихту рідної землі і кілька камінців із дна річки Прут, які поміщені при надгробку як символ Батьківщини ${ }^{32}$.

\section{Образ творця}

В уявленні Ольги Гоффманн, яка спирається на успадковані спогади, Василь Ткачук є великим, забутим і недооціненим сьогодні творчим талантом.

\footnotetext{
28 Інтерв'ю з Ольгою Гоффманн від 4 серпня 2018 року...

29 Ibidem.

30 Розмова з Ольгою Гоффманн від 1 квітня 2019 року...

31 Ibidem.

32 Інтерв'ю з Ольгою Гоффманн від 4 серпня 2018 року...
}

Slavica Wratislaviensia 173, 2020

(C) for this edition by CNS 
Такий залишився й у спогадах очевидців, які передали їх дочці письменника. За іiі словами, незважаючи на факт, що мати говорила небагато, найбільше уваги приділяла саме його таланту („Коли говорила [мати. - А. Г.-Ш.]), то тільки добре і про Його талант" $\left.{ }^{33}\right)$. Прикметно, що Ольга Гоффманн заперечувала, що Ткачук наслідував творчу манеру свого великого попередника Василя Стефаника. В інтерв'ю дочка письменника наголошувала невдоволеність батька з приводу спроб закидати йому епігонство: „Обурювався, коли порівнювали його творчість 3 творчістю Василя Стефаника, якого, мовляв, мав наслідувати" 34 . Підкреслюючи паралельне зростання обох творців, дочка письменника вказувала на суттєву, на іiї думку, різницю у можливостї творчого зростання Стефаника і Ткачука:

Є суттєва різниця між родиною Василя Стефаника, народженого в багатій селянській родині [i, відповідно, родиною Василя Ткачука. - А. Г.-Ш.]. Його мати могла приділити належну увагу талановитому синові, тоді як бідна [Ткачукова мати] неписьменна, яка працювала, щоб утримати своїх дітей, не мала такої можливості. Стала вдовою у 1922 році $^{35}$.

На наше питання про художні деталі творчості новеліста, його можливі плани на майбутнє Ольга Гоффманн в принципі уникала відповіді, (пор. „Не можу Вам відповісти на це питання. Просто немає в мене знання на цю тему"36), ймовірно через їх незнання, а втім виявила добру обізнаність 3 тематикою його творчості, вказуючи свої улюблені новели. На наше прохання назвати їх, дочка письменника відповіла: „Думаю, що «Буря» і «Ріка». Мальовничі описи, незрівнянні порівняння, мовляв, проза живописана словом"37.

У розмові з нами Ольга Гоффманн неодноразово підкреслювала унікальність батька — майбутнього письменника на тлі родини Ткачуків, тим паче, що ні його старша сестра Марійка, ні тим більше розумово неповноцінний старший брат Олександр нічим особливим не виділялися. Цікаво, що вбачаючи в батькові непересічну художню обдарованість („нешліфований діамант”), причин того дочка письменника шукає по-перше, в шляхетному (угорському) походженні батька, що мовляв зроджений із „роману на мент” його матері й угорського красеня-офіцера, i, по друге: у вихованні матір'ю, якої був пещенцем, про що згадувала в інтерв’ю: „Василько був улюбленцем матері. Найбільш тішило іiі його бажання вчитися. Кохала його і він любив ії̈ великою любов'ю $[\ldots]^{338}$.

Ольга Гоффманн не тільки вбачала в батьку великий художній талант, але і висловила переконання, що і в нього самого була віра у власні творчі можливості. На наше питання, чи митець дорожив своїми новелами, дочка
33 Ibidem.
34 Ibidem.
35 Ibidem.
36 Ibidem.
37 Ibidem.
38 Ibidem. 
письменника відповіла ствердно: „Думаю, що цінував свою творчість, адже вона принесла йому успіх і славу у львівському середовищі"39.

$$
* * *
$$

Маріанна Гірш, пропонуючи поняття постпам'яті, підкреслювала головне для цього концепту почуття часо-просторового віддалення від безпосереднього досвіду глибокої травми, який, попри далеку відстань між безпосередньо травмованими і їхніми нащадками, зумовив і сформулював міжпоколіннєвий травматичний наратив на довгі роки ${ }^{40}$. Відтак, американська дослідниця відвідала Чернівці — місто, в якому народилися іiї батьки, долаючи надскладний шлях ,між поняттям і досвідом, інтелектуальним i афективним чи соматичним простеженням питання міжпоколіннєвої трансмісії травматичного минулого" 41 .

У випадку нашого дослідження Ольга Гоффманн з приводу старшого віку і надломаного здоров’я, не могла здійснити поїздки до джерел, хоча безперечно це було іiі великим бажанням. Коротку подорож до Іллінців реалізувала у 1956 році вісімнадцятирічною дівчиною, але, як сама неодноразово підкреслювала, тоді у неї не спрацювала свідомість місії зберегти пам'ять про батька, не було в неї і непереборного стремління до відновдення його імені. У проведеному нами інтерв' ю Ольга Гоффманн згадувала зате про багатократні спроби iii матері, Марії Януш, дізнатися в Іллінцях і Львові про долю чоловіка Василя Ткачука. Щойно після смерті Сталіна Ткачукова сестра, Марійка, написала Ольжиній матері листа, а через рік вони здійснили вказану вище подорож.

Зустріч з тіткою, сестрами бабусі з боку батька була надзвичайно зворушливою. Літні жінки пильно вдивлялися в мене, шепочучи: „Василько”. На жаль, моя бабуся Олена вмерла тієї ж весни. Не було в мене можливості зустріти матері мого батька. На превеликий жаль ${ }^{42}$.

Подорож до Іллінців, по суті від імені Ольги Гоффманн і при її свідомому заангажуванні ${ }^{43}$, удалося здійснити нам, завдяки чому було проведених три інтерв'ю: з Людою Шиховою - дочкою Романа Ризюка, багатолітнього директора Народного музею історії села Іллінці, пристрасного збирача і цінувальника творчості Василя Ткачука; з Анною Федорійчук — щойно віднайденою родичкою письменника, онукою рідної сестри його матері, яка

39 Ibidem.

40 Див. A. Ubertowska, Praktykowanie postpamięci. Marianne Hirsch i fotograficzne widma z Czernowitz..., c. 269.

41 Ibidem.

42 Інтерв ю з Ольгою Гоффманн від 4 серпня 2018 року...

43 Дізнавшись про нашу поїздку в Іллінці, Ольга Гоффманн передала Народному музею історії села Іллінці певну грошову суму, а також зобов'язала нас пом'янути нещодавно померлого Романа Ризюка, покласти квіти і запалити свічку на могилі цього невтомного популяризатора творчої спадщини Василя Ткачука. 
живе в Іллінцях, але досі не знала дочки письменника; із Миколою Сулятицьким - земляком Ткачука - гуцулом, вихідцем із Снятинщини, професором Кафедри українознавства і філософії Івано-Франківського національного медичного університету. Указані „успадковані” спогади односельчан і родички Василя Ткачука, записані нами у формі інтерв’ю, „успадкувала” Ольга Гоффманн, знов потрапляючи у ситуацію „нарацій, що передаються”. Через два місцяці, у жовтні 2018 року Ольга Гоффманн мала ще одну нагоду отримати „успадковані” інформації про батька і письменника - Василя Ткачука, коли ії віднайдена родичка - Анна Федорійчук, відвідала Щецин. На цей раз були це вдвічі „успадковані” спогади, оскільки троюрідна сестра дочки письменника була тоді малою дитиною і не пам'ятала Василя Ткачука, а лише спогади про нього, що їх охоче оприлюднювала згорьована тугою за погиблим сином Ткачукова мати - Олена. Інформації Анни Федорійчук унікальні тим більше, що вона зросла в атмосфері культу надзвичайно талановитого члена родини Ткачуків і всі їі власні спогади, могла передати троюрідній сестрі.

Основною роллю постпам'яті, на думку дослідників ${ }^{44}, \epsilon$ відновлення можливості комунікації. Друге і чергові покоління, які не були безпосередньо травмовані війною, хочуть від імені батьків і дідів і водночас всупереч їхньому мовчанню повернути пам'ять про травмованих. Успадковані спогади Ольги Гоффманн vel Ткачук відіграли першорядну роль у відновленні пам'яті про Василя Ткачука. Безперечно вони певною мірою інтимізовані, що підтвердила у розмові з нами і сама дочка письменника (пор. „Он стільки в мене спогадів, збережених у пам'яті, а може в серці, про мого Батька і мою родину" ${ }^{45}$ ). Разом із писемними джерелами (літературною критикою 30-х років, архівними документами і зафіксованими спогадами нечисленних очевидців) та старими фотографіями творять цілісний трьохіпостасний його образ - як характерологічно складної, проте доброї і щирої людини, зокрема батька, як нещасної жертви тодішньої радянської влади, урешті, як талановитого, а то й унікального творця, який повністю заслуговує посісти гідне місце в пантеоні класиків українського письменства, що саме здійснюється на наших очах.

\section{Бібіографія}

Čerepanin V., Proâvlenì fotografologï̈, https://dt.ua/CULTURE/proyavleni_fotografologiyi.htm. Dvanadcâtka. Najmolodšal'vivs'ka literaturna bogema 30-h rokiv XX stolittâ: Antologiâ urbanìstičnö̈ prozi, red. V. Gabora, Vidavnictvo Pìramìda, L'vìv 2006.

44 Див. А. Mach, Poetyka postpamięci i etyka świadkowania w badaniach Marianne Hirsch, 2010, http://annamach.pl/wp-content/uploads/2016/01/Anna_Mach_humanistyka_xxi_2010.pdf [доступ: 19.02.2020].

45 Розмова з Ольгою Гоффманн від 1 квітня 2019 року... 
Goffmann O., Do storì̌čâa z dnâ Narodžennâvasilâ Tkačuka - spogadi dočki pis'mennika, „Ukraïns'kij al'manah" 2016.

Goffmann O., Hto takij Vasil' Tkačuk. Do sto-riččâa zdnì narodžennâ, „Naše Slovo”, 17.01.2016.

Gorak R., Zagublenij talant Vasilâ Tkačuka, [v:] V. Tkačuk, Zolotì dzvinki, pìdgotovka tekstìv, uporâd. ta pìslâslovo Romana Goraka, Vidavnictvo Aprìorì, L'vìv 2014.

Gornâtko-Šumilovič A., Burâ Vasilâ Tkačuka (Pro zabutu novelu ,Zagublenogo talantu”), „Studia Ukrainica Posnaniensia" 6, 2018.

Gornâtko-Šumilovič A., Simvol čički v novelìsticì Vasilâ Tkačuka, „Studia Ukrainica Posnaniensia” 7, 2019.

Hirsch M., Family Pictures: Maus, Mourning and Post-Memory, „Discourse: Journal for Theoretical Studies in Media and Culture" 1992-1993, t. 15, № 2.

Horniatko-Szumiłowicz A., ,, Skromne obrazki wiejskie” Wasyla Tkaczuka (szkic do portretu pisarza zapomnianego), „Studia et Documenta Slavica” 2017, № 1.

Horniatko-Szumiłowicz A., Majsternist' zmalûvannâ žìnočih postatej v Novelisticì Vasilâ Tkačuka, [v:] Kobieta w zwierciadle języka i kultury, red. A. Archangielska, M. Hordy, Wydawnictwo Naukowe Uniwersytetu Szczecińskiego, Szczecin 2017.

Horniatko-Szumiłowicz A., Na terezah dolì (Motivi j obrazi smertì u novelìsticì Vasilâ Tkačuka), „Slavica Wratislaviensia” 168, 2019.

Horniatko-Szumiłowicz A., Vasil' Tkačuk. Miž tradiciê̂u ì novatorstvom. Naris problematiki, [v:] Tożsamość ukraińska wobec przemian XVII-XXI w., red. K. Jakubowska-Krawczyk, A. Nowacki, Wydawnictwo KUL, Lublin 2017.

İnterv 'û z Ol'gô̂ Goffmann vì 4 serpnâ 2018 roku. Privatnij arhìv avtorki stattì.

Mach A., Poetyka postpamięci i etyka świadkowania w badaniach Marianne Hirsch, 2010, http:// annamach.pl/wp-content/uploads/2016/01/Anna_Mach_humanistyka_xxi_2010.pdf.

Polìsuk Â., Pam 'ât' i postpam 'ât' (na materialì romanu Lìni Kostenko „ZZapiski ukraïns'kogo samašedšogo"), [v:] Postkolonializm. Generaciï. Kul'tura, red. T. Gundorovoï, A. Matusâk, Vidavnictvo Laurus, Kiïv 2014.

Rozmova z Ol'goû Goffmann vì 1 kvitnâ 2019 roku. Privatnij arhìv avtorki stattì.

Sinìtovič H., Žittêvij ì tvorčij šlâh Vasilâ Tkačuka, [v:] V. Tkačuk, Sinì čički. Noveli, peredm. H. Sinìtovič, Vidavnictvo Lìleâ-NV, İvano-Frankìvs'k 2013.

Tkačuk V., Sinì čìcki. Noveli, peredm. H. Sinìtovič, Vidavnictvo Lìleâ-NV, İvano-Frankìvs'k 2013. Ubertowska A., Praktykowanie postpamięci. Marianne Hirsch i fotograficzne widma z Czernowitz, „Teksty Drugie” 2013, № 4.

\section{Inherited Memories: Olga Hoffmann a.k.a. Tkachuk Brings Back the Memory of Her Father}

\section{Summary}

The subject of this article is to trace the memories inherited by Olga Hoffmann a.k.a. Tkachuk (born in 1938), the only daughter of Vasil Tkachuk (1916-1944), the "lost talent" of Ukrainian literature of the 1930s. The purpose of this article is to present a three-dimensional image of Tkachuk - as a man and a father; a victim of the new Soviet authority; a talented writer - emerging from his daughter's imagination based on inherited memories. Inherited memories collected during two interviews with Olga Hoffmann were analyzed according to post-memory theory. The conclusions of the analysis show that thanks to inherited memories, Olga Hoffmann was able to restore the memory of her father and writer not only for herself as his daughter, but also for pos- 
terity. Tkachuk, a talented man, whose premature death made him be forgotten, can already be recognized as one of the classics of Ukrainian literature.

Keywords: Olga Hoffmann, Vasil Tkachuk, memories inherited, post-memory theory, Ukrainian literature

\section{Wspomnienia odziedziczone: Olga Hoffmann vel Tkaczuk przywraca pamięć o ojcu}

\section{Streszczenie}

Tematem niniejszego artykułu jest prześledzenie wspomnień odziedziczonych Olgi Hoffmann vel Tkaczuk (ur. 1938) — jedynej córki Wasyla Tkaczuka (1916-1944) — „zagubionego talentu" ukraińskiej nowelistyki lat trzydziestych XX wieku. Celem artykułu jest zaprezentowanie trójwymiarowego obrazu Tkaczuka (człowieka i ojca — ofiary nowej władzy radzieckiej — utalentowanego pisarza), który zarysował się w wyobraźni córki na podstawie wspomnień odziedziczonych. Wspomnienia odziedziczone zebrane podczas dwóch wywiadów z Olgą Hoffmann poddano analizie według teorii postpamięci. Wnioski płynące z analizy pozwalają stwierdzić, że dzięki wspomnieniom odziedziczonym Olga Hoffmann mogła przywrócić pamięć o ojcu i pisarzu nie tylko dla siebie jako córki, lecz także dla potomnych. Wielki talent, którego przedwczesna śmierć odsunęła w zapomnienie, może już dziś zostać zaliczony w poczet klasyków literatury ukraińskiej.

Stowa kluczowe: Olga Hoffmann, Wasyl Tkaczuk, wspomnienia odziedziczone, teoria postpamięci, literatura ukraińska 